\title{
IMPROVEMENT SYSTEM OF BIOLOGICAL FACTORS MANAGEMENT IN THE BREEDING OF FARM ANIMALS
}

\author{
СОВЕРШЕНСТВОВАНИЕ СИСТЕМЫ УПРАВЛЕНИЯ БИОЛОГИЧЕСКИМИ ФАКТОРАМИ \\ В СЕЛЕКЦИИ СЕЛЬСКОХОЗЯЙСТВЕННЫХ ЖИВОТНЫХ
}

\author{
A. Shendakov, Doctor of Agricultural Sciences, professor \\ А.И. Шендаков, доктор сельскохозяйственных наук, профессор \\ Orel State Agrarian University, Orel City, Russia \\ Phone: +7 (4862) 76-10-21, E-mail: aish78@yandex.ru
}

Received October 16, 2012

\begin{abstract}
Due to economical transformations of 1990-s in the sphere of milking cows breeding its profitability has grown low on many Russian cow-breeding farms, which was accompanied by the deterioration of zootechnical registration, selection and analytical approach to salvation of agro industrial complex topical problems. It caused the necessity of animal breeding enterprises reorganization. The introduction of intensive technologies, intellectual and methodical potential of domestic and foreign science to the animal breeding set a number of new problems before zootechnicians and stock-breeders. One of these tasks - improving the management of breeding and, especially, its biological factors (heritability, genetic correlations, the effect of heterosis, etc.). The situation is complicated by the fact that currently used in the selection of inbreeding, which often leads to inbreeding depression on intensity of growth, live weight, reproductive qualities and other selection signs. For the decision it is problems us researches of influence of inbreeding on efficiency of Black-and-White cows have been conducted. In scientific work the results of a comparative evaluation of milk yield of cows with inbreeding and conventional breeding. In the scientific is work studied the percentage of heifers and steers at calving, the number of calves-twins, stillborn calves and abortions in inbreeding and normal of animals groups. Inbreeding no had significant effect on stillbirths. The percentage of Holstein genes may influence of the sexes ratio in their offspring. The article presents the analysis of the level of development and the trends of production and selection in dairy cattle breeding, given prognosis for pig-breeding in Russia, a scheme of management of biological factors of selection, is work said about results of selection of Black-and-White, Simmental and Holstein cattle, also pig in Orel region.
\end{abstract}

\section{АННОТАЦИЯ}

В связи с экономическими реформами 1990-х годов отрасль молочного скотоводства во многих хозяйствах РФ стала нерентабельной, что сопровождалось ухудшением учёта, понижением уровня селекционной работы и ослаблением аналитического подхода к решению задач АПК. Это привело к необходимости реорганизации животноводческих предприятий. Внедрение интенсивных технологий и интеллектуально-методического потенциала отечественной и зарубежной науки в животноводство поставило перед зоотехниками-селекционерами ряд новых задач. Одна из таких задач - совершенствование системы управления селекиии и, особенно, её биологическими факторами (наследуемостью, генетическими корреляциями, гетерозисом и пр.). Ситуация усложняется ещеё и тем, что в настоящее время в селекции применяется инбридинг, который часто ведет к проявлению инбредной депрессии по интенсивности роста, живой массе, воспроизводительным качествам и другим селекционным признакам. Для решения этой проблемы нами были проведены исследования влияния инбридинга на продуктивность коров. В работе приведень результаты оченки молочной продуктивности коров при инбридинге и обычной селекции. Изучено прочентное соотношение тёлочек и бычков при отёлах, количества двоен, мёртворожденных телят и абортов. Инбридинг не оказал сильного влияния на мёртворождаемость. Процент голитинских генов может оказывать влияние на распределение полов в потомстве. В статье представлен анализ уровня развития и обоснованы направления селекционной работь в молочном скотоводстве, даны прогнозы для отрасли свиноводства в России, предложена схема управления биологическими факторами селекции. 


\section{KEY WORDS}

Selection; Black-and-White cattle; Simmental cattle; Holstein cattle; Pig; Inbreeding; Stillbirth; Calving difficulty.

\section{КЛЮЧЕВЫЕ СЛОВА}

Селекиия; Чёрно-пёстрый скот; Симментальский скот; Голитинский скот; Свиньи; Инбридинг; Мёртворождённость; Трудные отёльл.

Параметры селекции сельскохозяйственных животных условно можно разделить на селекционные, биологические и экономические $[10,11,12]$. Как правило, при оптимизации программ селекции основными являются селекционные параметры, такие, как процент выбраковки коров из стада, количество дочерей для оценки племенной ценности быкапроизводителя и т.п. На них зоотехникселекционер может воздействовать за счёт отбора и комплекса организационных мероприятий, что, в конечном итоге, существенно определяет селекционные дифференциалы и эффекты селекции по наиболее важным продуктивным признакам. К биологическим параметрам селекции можно отнести генетическую изменчивость и генетические корреляции между селекционными признаками, процент оплодотворяемости, вероятность рождения телёнка, тёлки или бычка. Согласно сложившимся представлениям в селекции, воздействовать на данные параметры крайне сложно, однако от их величин во многом зависит эффективность селекционного процесса.

Среди биологических параметров селекции целесообразно выделять такие генетические параметры, как частота генотипов и аллелей. Они имеют значение в маркерной селекции и при частотно-зависимом отборе. При этом в литературе приводятся данные о различных причинах корреляции между группами крови и продуктивностью животных - плейотропии, сцеплении генов и гетерозисе [1]. Известно, что гены, кодирующие систему EAF (Erythrocyte Antigen F), находятся на 15 хромосоме, а открытие в этой системе антигена $\mathrm{V}^{\prime}$ позволяет лучше понять сущность эволюции скота [2]. При этом многие породы скота родственного происхождения имеют высокий индекс иммуногенетического сходства $\left(r_{i}=0,64-0,89\right)$, хотя у черно-пёстрых и красно-пёстрых голштинов обнаружено существенное отличие по концентрации эритроцитарных антигенов $\mathrm{B}_{2}, \mathrm{I}_{1}, \mathrm{I}_{2}, \mathrm{~T}_{1}$, $\mathrm{Y}_{1}, \mathrm{E}_{2}^{\prime}, \mathrm{G}^{\prime}, \mathrm{I}^{\prime}, \mathrm{I}_{2}^{\prime}, \mathrm{Q}^{\prime}, \mathrm{C}_{2}, \mathrm{~W}, \mathrm{X}_{1}, \mathrm{X}_{2}, \mathrm{~L}^{\prime}, \mathrm{V}, \mathrm{S}_{1}$ и $\mathrm{S}_{2}$. По данным С. Исламовой и др., у симменталов отсутствуют антигены $\mathrm{P}_{2}, \mathrm{Y}_{1}, \mathrm{~A}_{2}^{\prime}, \mathrm{P}_{2}^{\prime}$, а $\mathrm{T}_{2}$ имеет наибольшую концентрацию [5], однако в Башкортостане также часто встречаются факторы $\mathrm{W}$ и $\mathrm{F}$, не обнаружены $\mathrm{Z}^{\prime}, \mathrm{R}_{1}, \mathrm{X}_{1}, \mathrm{M}^{\prime}, \mathrm{V}_{1}^{\prime}, \mathrm{R}^{\prime}$ и пр. [31]. Факторы $\mathrm{C}^{\prime}, \mathrm{C}_{2}, \mathrm{E}, \mathrm{L}, \mathrm{L}^{\prime}, \mathrm{R}_{2}, \mathrm{X}_{1}$ и $\mathrm{X}_{2}$ встречаются у чёрно-пёстрых коров, выбраковываемых и по старости, и по причинам различных заболеваний, в то время как $\mathrm{B}_{2}, \mathrm{H}^{\prime}, \mathrm{L}-$ по причине мастита, $\mathrm{C}, \mathrm{R}$ и $\mathrm{X}_{2}{ }_{2}-\mathrm{y}$ коров с заболеваниями конечностей, $\mathrm{C}_{1}-\mathrm{y}$ больных лейкозом. Частота антигена $\mathrm{A}_{1}$ у коровдолгожительниц составляет 0,0566 , а при болезнях сердца, эндометрите и пневмонии - до 0,1818 [7]. Независимо друг от друга Г. А. Романенко [26] и Н. И. Хайруллина с соавторами [31] приводят в качестве желательного для чёрно-пёстрого скота антиген $\mathrm{G}^{\prime \prime}$. В работе И. В. Кузнецовой [9] сказано, что у чёрнопёстрых коров Рязанской области распространён аллель $\mathrm{G}_{2} \mathrm{Y}_{2} \mathrm{E}_{3}^{\prime} \mathrm{Q}^{\prime}$, который также часто встречается и на Урале [26]. Вместе с тем, большинство научных работ в настоящее время посвящено изучению возможности маркировки тех или иных качеств у коров (высокого удоя, долголетия, заболеваемости и пр.), остаются недостаточно исследованными эволюционные процессы в породах, маркерная способность антигенов и генетических кластеров, сходство по аллелям сложных локусов и пр.

В связи с активным внедрением в скотоводство новых методов биотехнологии $[4,6$, $28,50]$ исследованиями многих авторов доказано, что технологические свойства молока зависят от их генотипа по локусу гена каппаказеина. Молоко коров с генотипом $\mathrm{AB}$ и $\mathrm{BB}$ под действием сычужного фермента свёртывается раньше, чем молоко коров с генотипом АА. Используя быков, в геноме которых содержится аллель В каппа-казеина (генотип АВ и $\mathrm{BB}$ ), можно не только поддерживать, но и увеличивать концентрацию аллеля В у маточного поголовья $[29,30,32]$. Однако в настоящее время недостаточно изученным остаётся вопрос изменения величины удоев при повы- 
шении концентрации гена В в стадах молочного скота.

Кроме того, в настоящее время многие зарубежные исследования посвящены изучению структуры фенотипической и генетический изменчивости, активно внедряется метод BLUP, применяется индексная селекция и подробный генетико-статистический анализ.

Таким образом, изучение биологических параметров и математическое обоснование генетических процессов в селекции животных имеет научно-практическое значение. Накопленный опыт биометрии при этом раскрывает новые возможности при изучении селекционно-генетического процесса в животноводстве.

\section{МАТЕРИАЛЫ И МЕТОДЫ ИССЛЕДОВАНИЙ}

Для решения этих задач в 2004 году совместно с ОАО «Орловское» по племенной работе нами была начата комплексная работа по модернизации селекции молочного скота. Были разработаны селекционно-генетические планы для 15 ведущих хозяйств Орловской области: ОПХ «Стрелецкое» и «Красная Звезда», ЗАО «Славянское», «Берёзки» и «Куракинское», ОАО «Агрофирма Мценская», «Орловская Нива», СПК им. Мичурина и «Малиновский», ООО «Юпитер», «Маслово», «Русь», «Урицкий Агрокомплекс» и др. Была изучена молочная продуктивность коров в зависимости от генотипа и линейной принадлежности, оценены быки-производители. Воспроизводительные качества коров были изучены по 6326 отёлам в 7 хозяйствах Орловской области. Общая схема исследований представлена на рисунке 1.

Коэффициенты повторяемости были определены по формуле Н. А. Плохинского: $r_{w}=\frac{r_{1}+r_{2}+\ldots .+r_{n}}{n}$, где $r_{1}, r_{2}$ и т. д. - корреляция между смежными периодами выращивания, $\mathrm{n}$ - количество коэффициентов корреляции.

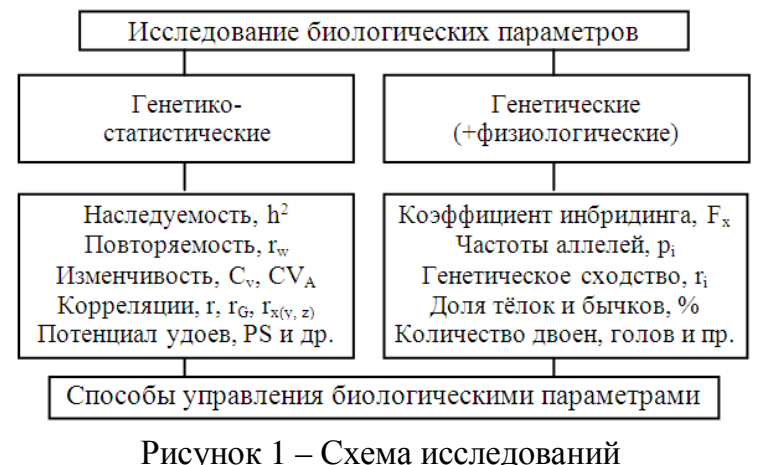

Рисунок 1 - Схема исследований
Коэффициенты наследуемости за смежные циклы продуктивности определяли по формуле Ле Руа: $h_{n}^{2}=\frac{h^{2} \cdot n}{1+(n-1) \cdot r_{w}}$, где $h^{2}=2 b_{\text {м-д. }}, n-$ количество лактаций. Были изучены множественные корреляции между селекционными признаками коров и свиней: $r_{x(y, z)}=\sqrt{\frac{\left(r^{2}{ }_{x y}+r^{2}{ }_{x z}-2 r_{x y} r_{x z} r_{y z}\right)}{1-r^{2}{ }_{y z}}}$ (по Г. Ф. Лакину [13]). Генетическая корреляция между промерами и удоем, удоем и содержанием жира в молоке определялась по формулам Хейзеля:

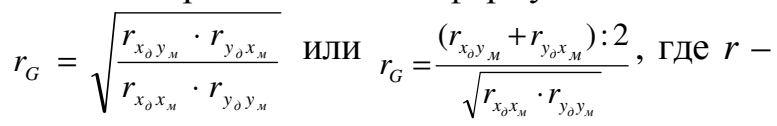
фенотипические коэффициенты корреляции между признаками $x$ и $y$ у дочерей и матерей [25].

Дисперсионный анализ проводили с определением критерия Краскелла-Уоллиса $H=\frac{\left(\sum\left(\sum x_{i}\right)\right)^{2}}{N}$, общей девиаты $D_{y}=\Sigma\left(\Sigma x_{i}^{2}\right)-H$, факториальной девиаты $D_{x}=\frac{\sum\left(\sum x_{i}\right)^{2}}{n}-H$, силы влияния $h_{x}^{2}=D_{x}: D_{y}$ (с использованием $\mathrm{F}$ критерия Фишера). Для прогнозирования поголовья свиней в России применялись уравнения регрессий, выраженные гиперболами первого и второго порядка: $\bar{y}_{x}=a+\frac{b}{x}$ и $\bar{y}_{x}=a+\frac{b}{x^{2}}$ [13]. Генетический потенциал животных был определён по формуле, приведённой Р. Шилером с соавторами: $P S=\frac{n \cdot r_{w}}{1-r_{w}+n \cdot r_{w}} \cdot P_{x}+\frac{1-r_{w}}{1-r_{w}+n \cdot r_{w}} \cdot A$, где $n$ - число повторных циклов продуктивности, $r_{w}-$ коэффициент повторяемости, $P_{x}-$ средняя продуктивность оцениваемого животного, $A-$ средняя продуктивность стада [49]. Генетическая вариация определялась по методике D. Houle (1992): ${ }_{C V_{A}}=\frac{\sqrt{V_{A}}}{\bar{x}} \cdot 100$, где $\bar{x}-$ фенотипическая величина среднего значения селекционного признака в стаде, $\mathrm{V}_{\mathrm{A}}$ - коэффициент аддитивной генетической изменчивости [51]. Коэффициент инбридинга (возрастания гомозиготности) вычисляли по формуле РайтаКисловского: $F_{x}=\sum\left[\left(\frac{1}{2}\right)^{n_{1}+n_{2}-1} \cdot\left(1+f_{a}\right)\right] \cdot 100$, где $\mathrm{n}_{1}$ и $\mathrm{n}_{2}$ - ряд, в котором находится общий предок с материнской и отцовской стороны, $f_{a}-$ величина коэффициента инбредного предка [25]. 
Величина концентрации эритроцитарных антигенов была определена как по методике Е. К. Меркурьевой [25], так и по формуле: $p_{i}=\frac{n_{i}}{N_{A}}$,

где $n_{i}$ - число животных, несущих в генотипе данный антиген, $N_{A}$ - сумма обнаруженных антигенов у всех животных. Сходство по аллелям одного локуса групп крови было определено по формуле Животовского: $r_{i}=\sum \sqrt{x y}$, где $x$ и $y-$ частоты аллелей данного локуса. Общее иммуногенетическое сходство было вычислено за счёт суммирования коэффициентов сходства по каждому локусу и переведено в проценты. Также была использована формула Майяла и Лингстрема [25] для вычисления общего генетического сходства: $r=\frac{\sum x_{i} \cdot y_{j}}{\sqrt{\sum x_{i}^{2} \cdot \sum y_{j}^{2}}}$, где $x_{i}$ и $y_{j}$ частоты одних и тех же аллелей (антигенов) разных учтенных локусов в двух сопоставляемых группах животных. Тестирование групп крови СП «Сабурово» проходило в лаборатории иммуногенетики ВНИИ животноводства.

Теоретическая основа исследований строилась на формуле: $y=\mu+G+B+e$, где у - абсолютная фенотипическая ценность, $\mu$ - среднее значение признака в популяции (стаде), G генетические факторы, В - систематические средовые факторы, е - случайные факторы. При изучении структуры фенотипической изменчивости использовалась формула: $P=G+E$, где $\mathrm{G}$ - генотипическая изменчивость, $\mathrm{E}$ - паратипическая изменчивость. Методика вычисления частоты встречаемости аллелей была построена на основе формулы Харди-Вайнберга $(p A+q a)^{2}=\left(p^{2} A A+2 p q A a+q^{2} a a\right)[1,25]$.

В работе были использованы каталоги быков-производителей ОАО «ЦСИО» (2001 и 2008), ОАО «Орловское (2011), а также немецкий каталог «Spermex Top Sires» (2010). Статистический анализ был проведён в компьютерных программах «Microsoft Excel» и «Статистика».

\section{РЕЗУЛЬТАТЫ СОБСТВЕННЫХ ИССЛЕДОВАНИЙ}

Результаты скрещивания чёрно-пёстрых и палево-пёстрых коров с голштинскими быками нами были опубликованы в ряде статей [8, 1422, 33-43], из которых следует, что для производства молока оптимальной может считаться любая кровность (от 1/8 до 7/8 по голштинам) в зависимости от множества факторов - качества кормления, содержания, технологии доения и пр. Однако нами также установлено, что при увеличении в рационе коров кормовых единиц оптимальная кровность растёт: на каждые 150-200 к. ед. дополнительно в год приходится увеличение оптимальной доли голштинских генов на $12,5 \%$, а для коров с кровностью $87,5-100 \%$ по голштинам требуется на 15002000 к. ед. больше, чем для низкокровного и чистопородного чёрно-пёстрого скота [43, 44, 45]. Несмотря на решённый нами вопрос об оптимальной кровности и выводе о большем влиянии отцов на генетический прогресс в популяциях крупного рогатого скота [3, 46], нами установлено, что процент генов по голштинской породе достоверно влияет на эффект селекции по удою, коррелятивные сдвиги жирности молока и живой массы [47], а также на рентабельность селекционного процесса и дополнительную прибыль [48]. Линейная принадлежность, согласно нашим исследованиям, имеет противоречивое значение, а многие линии могут по-разному показывать себя в хозяйствах в зависимости от многих факторов $[27,44]$. Нами определено, что весовые коэффициенты селекционных признаков у чистопородных и помесных коров существенно отличаются [48], а процент генов голштинской породы влияет не только на аддитивную генетическую изменчивость, но и на генетические корреляции между удоем и жирностью молока [47]. В результате проведённых исследований была разработана стратегия увеличения молочной продуктивности коров Орловской области [23].

Из таблицы 1 следует, что наибольшим генетическим потенциалом удоя обладали матери канадских быков, семя которых реализовывало ОАО «Московское» в 2004 году, 12376 кг молока при жирности 4,45\%. Для немецких быков была характерна наибольшая жирность молока у матерей $(4,70 \%)$. Вместе с тем, матери матерей американских быков отличались наибольшим удоем - 12175 кг при жирности 4,75\%, а матери отцов у быков немецкой селекции имели самый высокий удой, что составляло 13206 кг молока жирностью $4,14 \%$. Количество молочного жира у всех предков являлось рекордным, независимо от происхождения. Однако от 2124 дочерей немецкого происхождения в хозяйствах РФ было получено в среднем 6465 кг молока, что превысило дочерей быков американского и канад- 
ского происхождения на 150 и 1596 кг соответственно. Также они были лучшими по количеству молочного жира - 257,3 кг.

Таблица 1 - Продуктивность предков и дочерей голштинских быков ОАО «Московское»

\begin{tabular}{|c|c|c|c|}
\hline \multirow{2}{*}{ Показатели } & \multicolumn{3}{|c|}{ Происхождение } \\
\hline & Германия & СШ̈Ӓ & Канада \\
\hline Количество быков & 24 & 14 & 8 \\
\hline Количество дочерей & 2124 & 754 & 749 \\
\hline Продуктивность матерей: & & & \\
\hline Удой, кг & 11435 & 11556 & 12376 \\
\hline Жирность молока, \% & 4,70 & 4,49 & $4,45^{*}$ \\
\hline Жир, кг & 537,4 & $518,9^{*}$ & 550,7 \\
\hline$\frac{\text { Продуктивность }}{\text { матерей матерей: }}$ & & & \\
\hline Удой, кг & 10739 & $12175^{* *}$ & $10051^{*}$ \\
\hline Жирность молока, \% & 4,57 & $4,75^{*}$ & $4,34 *$ \\
\hline Жир, кг & 490,8 & $578,3 * *$ & $436,2 *$ \\
\hline Продуктивность & & & \\
\hline матерей отцов: & & & \\
\hline Удой, кг & 13206 & 13056 & $10859 * 2$ \\
\hline Жирность молока, \% & 4,14 & $3,92 * *$ & $\begin{array}{c}3,99 * \\
433, * * *\end{array}$ \\
\hline Жир, кг & 546,7 & 511,8 & \\
\hline Продуктивность дочерей: & & & \\
\hline Удой, кг & 6465 & 6315 & $4869 * * *$ \\
\hline Жирность молока, \% & 3,98 & 3,83 & $3,80 * *$ \\
\hline Жир, кг & 257,3 & 241,9 & $185,0 * * *$ \\
\hline
\end{tabular}

Примечание: *-p $<0,05, * *_{-} \mathrm{p}<0,01, * * *_{-} \mathrm{p}<0,001$

Таблица 2 - Корреляция между удоем и жирностью молока у материнских предков голштинских и чёрно-пёстрых быков-производителей ОАО «ЦСИО»

\begin{tabular}{|c|c|c|c|c|c|}
\hline \multirow[b]{2}{*}{ Происхождение } & \multirow[b]{2}{*}{$\mathrm{n}$} & \multicolumn{2}{|c|}{ Матери } & \multicolumn{2}{|c|}{ Матери матерей } \\
\hline & & 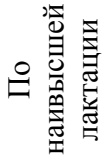 & 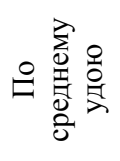 & 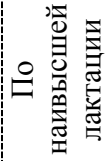 & 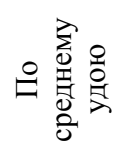 \\
\hline Отечественное & 27 & $\begin{array}{l}-0,247 \\
\pm 0,194\end{array}$ & $\begin{array}{c}0,212 \\
\pm 0,196\end{array}$ & $\begin{array}{c}0,025 \\
\pm 0,200\end{array}$ & $\begin{array}{c}0,279 \\
\pm 0,192\end{array}$ \\
\hline Канадское & 23 & $\begin{array}{l}-0,107 \\
\pm 0,217\end{array}$ & $\begin{array}{c}-0,398 \\
\pm 0,200 *\end{array}$ & $\begin{array}{c}0,254 \\
\pm 0,211\end{array}$ & $\begin{array}{l}-0,109 \\
\pm 0,217\end{array}$ \\
\hline Европейское & 28 & $\begin{array}{c}0,066 \\
\pm 0,196\end{array}$ & $\begin{array}{c}0,114 \\
\pm 0,195\end{array}$ & $\begin{array}{l}-0,373 \\
\pm 0,182\end{array}$ & $\begin{array}{c}-0,405 \\
\pm 0,179 *\end{array}$ \\
\hline Всё поголовье & 78 & $\begin{array}{c}0,097 \\
\pm 0,114\end{array}$ & $\begin{array}{l}-0,043 \\
\pm 0,114\end{array}$ & $\begin{array}{c}0,005 \\
\pm 0,115\end{array}$ & $\begin{array}{l}-0,053 \\
\pm 0,114\end{array}$ \\
\hline
\end{tabular}

Примечание: *-p $<0,05, * *-\mathrm{p}<0,01, * * *-\mathrm{p}<0,001$

Из таблицы 2 следует, что корреляция между средним удоем и жирностью молока у матерей голштинских и чёрно-пёстрых быковпроизводителей ОАО «ЦСИО» отечественного происхождения была выше, чем у матерей канадских быков, на $0,610(\mathrm{p}<0,05)$. Также матери матерей отечественных быков превзошли по аналогичной корреляции матерей матерей европейских быков-производителей на $0,684(\mathrm{p}<0,05)$, а следовательно, при использовании отечественных генетических ре- сурсов можно более эффективно повышать жирность молока в селекции чёрно-пёстрых коров по удою.

Согласно расчётам по формуле Ле Руа, коэффициент наследуемости $\left(\mathrm{h}_{\mathrm{n}}^{2}\right)$ удоя от 2 к 6 лактации у коров-рекордисток в Орловской области возрастал и на последнем цикле продуктивности составлял 0,154 , по процентному содержанию жира в молоке и количеству молочного жира он был равен 0,829 и 0,703 соответственно (рис. 2). Это, по-видимому, объяснимо тем, что к концу продуктивного использования коровы реализовывали свой генетический потенциал максимально.

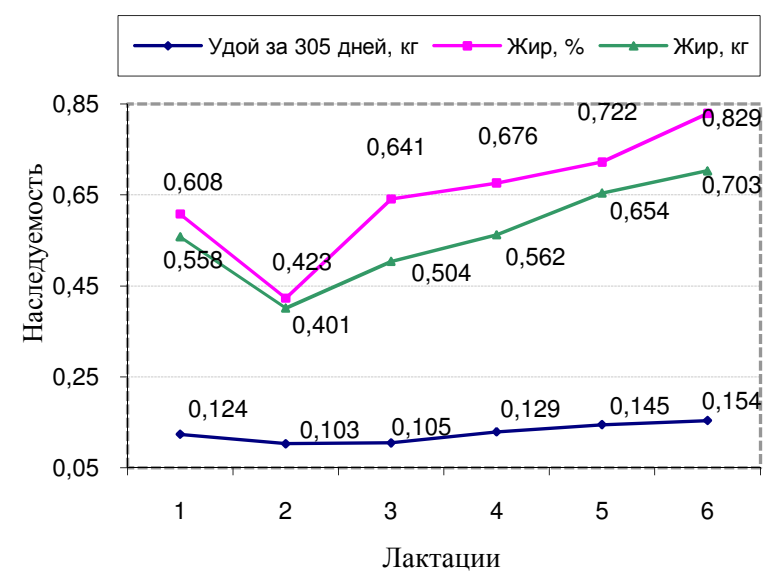

Рисунок 2 - Коэффициенты наследуемости признаков молочной продуктивности у чёрно-пёстрых коров-рекордисток в зависимости от числа смежных лактаций, $h_{n}^{2}$

Анализ показал, что наибольшая детерминация фенотипа генотипом по удою и количеству молочного жира в ООО «Фатнево» была характерна для симментальских коров линии Флориана - 0,680 и 0,916 соответственно (рис. 3). Также была получена высокая детерминация по этим признакам у коров линий С. Т. Рокит и Мергеля. По всему поголовью она составила 0,319 и 0,316 , что также можно считать положительным результатом при голштинизации палево-пёстрого скота. В хозяйстве было достаточно большое поголовье, принадлежащее разным линиям, детерминация признаков молочной продуктивности в которых являлась достаточно высокой. 


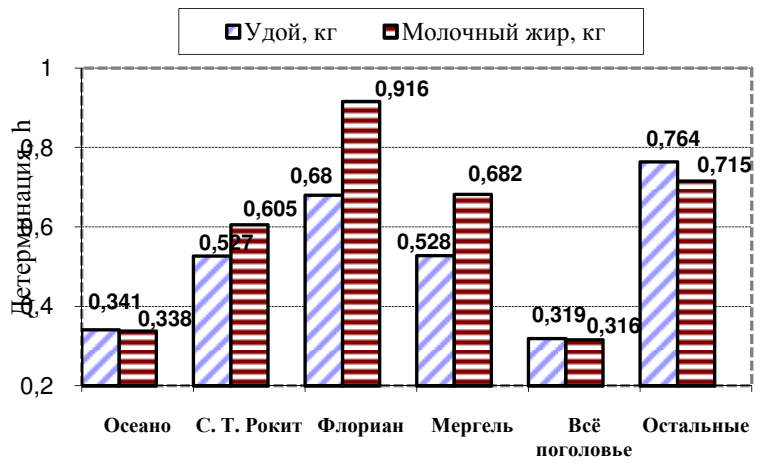

Рисунок 3 - Детерминация признаков генотипом у коров разных линий в ООО «Фатнево» Орловской области, h

В связи с наличием высокой детерминации фенотипа генотипом в отдельных линиях хозяйства прослеживалась положительная генетическая связь между удоем и жирностью молока. Положительные коэффициенты фенотипической связи привели к высокой генетической корреляции $\left(\mathrm{r}_{\mathrm{G}}\right)$ у коров линий С.Т.Рокит, Радониса и Важного в ООО «Фатнево» - 0,507, 0,529 и 0,683 соответственно (табл. 3).

Таблица 3 - Генетическая корреляция между удоем и жирностью молока у коров разных линий в ООО «Фатнево» $(\mathrm{n}=180)$

\begin{tabular}{|c|c|c|c|c|c|}
\hline \multirow[b]{2}{*}{ Линия } & \multicolumn{4}{|c|}{ Фенотипическая корреляция } & \multirow[b]{2}{*}{$r_{G}$} \\
\hline & $\begin{array}{c}\text { Удой } \\
\text { дочерей } \\
\text { - удой } \\
\text { матерей }\end{array}$ & $\begin{array}{l}\text { Жир } \\
\text { дочерей } \\
\text { - жир } \\
\text { матерей }\end{array}$ & $\begin{array}{l}\text { Жир } \\
\text { матерей } \\
\text { - удой } \\
\text { дочерей }\end{array}$ & $\begin{array}{l}\text { удой } \\
\text { матерей } \\
\text { - жир } \\
\text { дочерей }\end{array}$ & \\
\hline С. Т. Рокит & 0,210 & 0,031 & 0,139 & 0,183 & $0,507 * *$ \\
\hline Радониса & $0,876^{* *}$ & $0,688^{* *}$ & $0,410^{*}$ & $0,413^{*}$ & $0,529 * *$ \\
\hline Важного & $0,875^{* *}$ & $0,414^{*}$ & $0,409^{*}$ & $0,413 *$ & $0,683 * * *$ \\
\hline Bce & 0,051 & 0,020 & 0,034 & 0,011 & $0,605^{* *}$ \\
\hline
\end{tabular}

Примечание: *- $<<0,05, * *_{-}$p $<0,01, * * *-p<0,001$.

Из таблицы 4 следует, что в ОПХ «Стрелецкое» наибольшую генетическую корреляцию имели коровы линии С. Т. Рокит $-0,804$. Для животных линии У. Идеал также была характерна положительная генетическая корреляция - 0,403. Коровы линии Р. Соверинг независимо от двух отрицательных значений имели положительную генетическую связь $(0,500)$. В то же время, для линии А. Адема была свойственна отрицательная корреляция $(-0,281)$, а у коров родственной группы Ривелино генетическую связь найти было невозможно из-за отсутствия аддитивного наследования.
Таблица 4 - Генетическая корреляция между удоем и жирностью молока у чёрно-пёстрых коров в зависимости от линейной принадлежности в ОПХ «Стрелецкое» Орловской области

\begin{tabular}{|c|c|c|c|c|c|c|}
\hline \multirow[b]{2}{*}{ Линия } & \multirow[b]{2}{*}{$\mathrm{n}$} & \multicolumn{4}{|c|}{ Фенотипическая корреляция } & \multirow[b]{2}{*}{$r_{G}$} \\
\hline & & 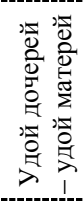 & 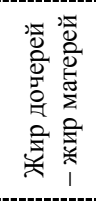 & 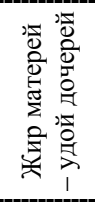 & 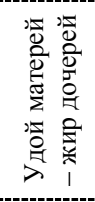 & \\
\hline А. Адема & 15 & 0,303 & 0,301 & 0,023 & $-0,193$ & $-0,281 *$ \\
\hline Ривелино & 38 & 0,299 & $-0,102$ & 0,176 & $-0,065$ & - \\
\hline У.Идеал & 182 & 0,195 & 0,066 & 0,029 & 0,072 & $0,403 *$ \\
\hline P. Соверинг & 212 & 0,196 & 0,068 & $-0,032$ & $-0,104$ & $0,500^{*}$ \\
\hline С. Т. Рокит & 106 & 0,096 & 0,192 & 0,128 & 0,093 & $0,804 * *$ \\
\hline
\end{tabular}

Примечание:

Ривелино - родственная группа;

$*_{-} \mathrm{p}<0,05, * *-\mathrm{p}<0,01, * * *_{-} \mathrm{p}<0,001$.

Наибольшую устойчивость удоя за завершённую лактацию в ОПХ «Стрелецкое» имели коровы с 12,5\% голштинских генов - 0,594. Это превысило чистопородных животных на 0,308. Высокие показатели множественной корреляции по удою первых трёх лактаций также имели коровы с 62,5 и 75\% голштинских генов - 0,412 и 0,414. Наиболее устойчивый удой за 305 дней был получен от коров с 87,5 и $37,5 \%$ генов голштинской породы - 0,648 и 0,641, что достоверно превысило контроль на 0,485 и 0,492 (см. таблицу 5).

Таблица 5 - Множественная корреляция между признаками первых трёх лактаций у чёрнопёстрых коров в зависимости от генотипа в ОПХ «Стрелецкое»

\begin{tabular}{|c|c|c|c|c|}
\hline \multirow[b]{2}{*}{$\% \mathrm{HF}$} & \multirow[b]{2}{*}{$\mathrm{n}$} & \multicolumn{3}{|c|}{ Селекционные признаки коров, $\mathrm{r}_{1(2,3)} \pm \mathrm{m}_{\mathrm{r}}$} \\
\hline & & $\begin{array}{l}\text { Удой за } 305 \\
\text { дней, кг }\end{array}$ & Жир, \% & $\begin{array}{c}\text { Живая мас- } \\
\text { са, кг }\end{array}$ \\
\hline 0 & 12 & $0,156 \pm 0,329$ & $0,541 \pm 0,280$ & $0,999 \pm 0,015$ \\
\hline 12,5 & 13 & $0,485 \pm 0,276$ & $0,698 \pm 0,226$ & $0,471 \pm 0,280 * *$ \\
\hline 25,00 & 57 & $0,341 \pm 0,128$ & $0,568 \pm 0,112$ & $0,486 \pm 0,119 * *$ \\
\hline 37,50 & 27 & $0,641 \pm 0,157^{*}$ & $0,143 \pm 0,202$ & $0,779 \pm 0,125$ \\
\hline 50,00 & 63 & $0,249 \pm 0,125$ & $0,051 \pm 0,129^{*}$ & $0,464 \pm 0,114^{* *}$ \\
\hline 62,50 & 44 & $0,568 \pm 0,129 *$ & $0,286 \pm 0,150$ & $0,623 \pm 0,122$ \\
\hline 75,00 & 46 & $0,248 \pm 0,148$ & $0,248 \pm 0,148$ & $0,032 \pm 0,378 * * *$ \\
\hline 87,50 & 10 & $0,648 \pm 0,437 *$ & $0,437 \pm 0,340$ & $0,776 \pm 0,238$ \\
\hline
\end{tabular}

Примечание:

$\mathrm{HF}$ - \% генов голштинской породы (0\% по голштинам контрольная группа);

$*-\mathrm{p}<0,05, * *-\mathrm{p}<0,01, * * *-\mathrm{p}<0,001$.

Высокими показателями устойчивости также обладали коровы с кровностью 5/8 0,568, хотя при увеличении кровности до 3/4 коэффициент множественной корреляции по- 
низился до 0,248. Полукровные коровы не отличались хорошими показателями устойчивости удоя. Наиболее устойчивая жирность молока была получена от коров с 12,5-25,0\% генов голштинской породы $\quad\left(\mathrm{r}_{\mathrm{x}(\mathrm{y}, \mathrm{z})}=0,698\right.$ $0,568)$, что значительно превысило показатель множественной корреляции других помесных генотипов, за исключением коров с 87,5\% генов голштинов, которые отличались невысокими удоями. По устойчивости живой массы точных тенденций получено не было, однако наибольшими показателями обладали чистопородные коровы, а также помеси с кровностью $37,5,62,5$ и $87,5 \%$ генов голштинской породы.

Таблица 6 - Множественная корреляция между признаками первых трёх лактаций у чёрнопёстрых коров разных линий в ОПХ «Стрелецкое»

\begin{tabular}{|c|c|c|c|}
\hline Линия & $\begin{array}{c}\text { Селекционные признаки коров, } \mathrm{r}_{12232} \pm \mathrm{m}_{\mathrm{r}} \\
\text { Удой за } 305 \\
\text { дней, кг }\end{array}$ & $\begin{array}{c}\text { Жир, } \\
\%\end{array}$ & $\begin{array}{c}\text { Молочный } \\
\text { жир, кг }\end{array}$ \\
\hdashline А. Адема & $0,305 \pm 0,287$ & $0,528 \pm 0,256$ & $0,102 \pm 0,300$ \\
\hdashline Ривелино & $0,367 \pm 0,129$ & $0,374 \pm 0,129$ & $0,259 \pm 0,134$ \\
\hdashline У.Идеал & $0,326 \pm 0,097$ & $0,168 \pm 0,101 *$ & $0,349 \pm 0,096$ \\
\hdashline Р. Соверинг & $0,288 \pm 0,114$ & $0,379 \pm 0,110$ & $0,260 \pm 0,115$ \\
\hdashline С. Т.Рокит & $0,219 \pm 0,252$ & $0,702 \pm 0,184$ & $0,273 \pm 0,248$ \\
\hline
\end{tabular}

Примечание:

Ривелино - родственная группа;

$*_{-} \mathrm{p}<0,05,{ }^{*} *_{-} \mathrm{p}<0,01, * * *-\mathrm{p}<0,001$.

Из таблицы 6 следует, что наибольшую устойчивость удоя за 305 дней лактации имели коровы родственной группы Ривелино 0,367. Это незначительно превысило коров линии А. Адема. Наиболее устойчивая жирность молока была получена от коров линии С. Т. Рокит $\left(\mathrm{r}_{\mathrm{x}(\mathrm{y}, \mathrm{z})}=0,702\right)$, а по количеству молочного жира все голштинские линии имели преимущество над чистопородными коровами на 0,157-0,247.

Согласно нашим опубликованным данным [48], независимо от лактации в стаде коров ОПХ «Стрелецкое» проявлялись высокие множественные корреляции удоя с жирностью молока и живой массой - до 0,732-0,811 $(\mathrm{p}<0,05)$. Дисперсионный анализ этих данных (см. рис. 4) подтверждает, что \% генов чёрнопёстрой голштинской породы достоверно влиял на множественные коэффициенты корреляции между удоем, жирностью молока и живой массой у коров $-31,08 \pm 7,65 \%(\alpha<5 \%)$. Лактация не имела сильного влияния на ко- эффициенты, поскольку был исключен фактор выбраковки $(2,16 \pm 10,86 \%)$. Это позволило нам сделать предположение о том, что совместное влияния \% голштинских генов и лактации $(37,21 \pm 6,97 \%)$ объяснимо усилением действия генотипа с возрастом. К неучтённым факторам в данном случае можно отнести паратипические факторы.

Принято считать, что в хозяйствах рождается $50 \%$ тёлок и $50 \%$ бычков, однако на практике даже без применения разделённого по полу семени распределение полов может быть неравномерным, а в иностранных моделях NYB и NPB [11] при определении необходимого количества быков-производителей в популяциях учитывается вероятность рождения не только телёнка, но и тёлки. Интересные данные приводят ирландские учёные $S$. Mc. Parland, J. F. Kearney, M. Rath и D. P. Berry в журнале «Dairy Science» (2007), где сказано, что у коров с коэффициентом возрастания гомозиготности $(\mathrm{Fx})$ от 20 до $30 \%$ рождается на 3-6\% больше тёлок в сравнении с аутбредными матерями [52]. Данное явление учёные объясняют теорией Trivers и Willard (1973), согласно которой ослабленным инбредной депрессией матерям проще выносить тёлку.

Из данных таблицы 7 следует, что у аутбредных коров СПК имени Мичурина, ЗАО «Куракинское» и ОПХ «Красная Звезда» рождается от 41,07 до $49,47 \%$ тёлок, от 1,13 до $6,41 \%$ телят рождаются мёртвыми. Коровы, у которых были отцами Падеграс, Миг и Дон дали 11 двоен - 6, 1 и 4 соответственно. У аутбредных коров ООО «Фатнево» было получено тёлок на $3,91 \%$ больше нормы. В ОПХ «Стрелецкое», согласно данным хозяйства, в 2008 году на 893 живых телёнка было получено всего 289 тёлок (или 32,36\%). Следует также заметить, что применение инбридинга в степенях от 1,5626 до $25 \%$ в чёрно-пёстром поголовье способствовало выравниванию распределения полов в потомстве $(49,66 \%$ тёлок), а в симментал-голштинском поголовье коров $\left(\mathrm{F}_{\mathrm{x}}=0,0488-12,5 \%\right)$ вело к некоторому ослаблению вероятности рождения тёлок, однако у 9 коров с $\mathrm{F}_{\mathrm{x}}=6,25-12,5 \%$ из 22 отёлов родилось на 2 тёлки больше, чем бычков. Также инбридинг способствовал в ООО «Фатнево» получению 5 двоен, или $4,88 \%$ от количества полученных телят. По всему чёрно-пёстрому поголовью из 4966 живых телят 
было получено 43,62\% тёлок, в изученном симментальском поголовье и его помесях было получено приблизительно одинаковое количество бычков и тёлок, а из 6074 живых телят в исследуемых хозяйствах $44,85 \%$ составили тёлки, рождение мёртвых телят на 6326 отёлов занимало 3,92\%, или 248 голов.

Таблица 7 - Воспроизводительные качества чёрно-пёстрого и симментальского голштинизированного скота в хозяйствах Орловской области

\begin{tabular}{|c|c|c|c|c|c|c|c|c|}
\hline \multirow{2}{*}{$\begin{array}{c}\text { Всего } \\
\text { изучено } \\
\text { отёлов }\end{array}$} & \multirow{2}{*}{$\begin{array}{c}\text { Живых } \\
\text { телят, } \\
\text { голов }\end{array}$} & \multirow{2}{*}{$\begin{array}{l}\text { Бычков, } \\
\text { голов }\end{array}$} & \multirow{2}{*}{$\begin{array}{c}\text { Тёлок, } \\
\text { голов } \\
(\%)\end{array}$} & \multirow{2}{*}{$\begin{array}{l}\text { Количество } \\
\text { двоен }\end{array}$} & \multirow[b]{2}{*}{ Аборты } & \multicolumn{2}{|c|}{ Мёртворожденных } & \multirow[b]{2}{*}{$\begin{array}{l}\text { Трудные } \\
\text { отёлы }\end{array}$} \\
\hline & & & & & & голов & $\begin{array}{l}\% \text { ко всем } \\
\text { отёлам }\end{array}$ & \\
\hline \multicolumn{9}{|c|}{$\begin{array}{l}\text { Аутбридинг (неродственное спаривание) } \\
\text { ЗАО «Славянское» (чёрно-пёстрый и симментальский, Верховский район) }\end{array}$} \\
\hline 645 & 622 & 348 & $274(44,05)$ & -1 & 5 & 23 & 3,57 & - \\
\hline \multicolumn{9}{|c|}{ СПК им. Мичурина (чёрно-пёстрый, Верховский район) } \\
\hline 1150 & 1137 & 670 & $467(41,07)$ & 11 & 1 & 13 & 1,13 & 6 \\
\hline \multicolumn{9}{|c|}{ 3АО «Куракинское» (чёрно-пёстрый, Свердловский район) } \\
\hline 811 & 759 & 389 & $370(48,75)$ & - & - & 52 & 6,41 & 3 \\
\hline \multicolumn{9}{|c|}{ ОПХ «Красная Звезда» (чёрно-пёстрый, Орловский район) } \\
\hline 1307 & 1225 & 619 & $606(49,47)$ & - & 3 & 82 & 6,27 & 8 \\
\hline \multicolumn{9}{|c|}{ ООО «Фатнево» (симментальский, Болховский район) } \\
\hline 619 & 588 & 271 & $317(53,91)$ & 3 & 4 & 31 & 5,01 & 24 \\
\hline \multicolumn{9}{|c|}{ ОПХ «Стрелецкое» (чёрно-пёстрый, Орловский район, по данным хозяйства) } \\
\hline 925 & 893 & 604 & $289(32,36)$ & - & 18 & 32 & 3,46 & - \\
\hline \multicolumn{9}{|c|}{ ООО «Шаблыкинский Агрокомплекс» (чёрно-пёстрый, Шаблыкинский район) } \\
\hline 499 & 498 & 272 & $226(45,38)$ & - & - & 1 & 0,20 & - \\
\hline \multicolumn{9}{|c|}{ Чёрно-пёстрый скот (СПК Имени Мичурина, ЗАО «Куракинское» и ОПХ «Красная Звезда») } \\
\hline 153 & 147 & 74 & $73(49,66)$ & 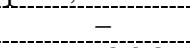 & - & 6 & 1,31 & 1 \\
\hline \multicolumn{9}{|c|}{ Симментальский (ООО «Фатнево») } \\
\hline 213 & 205 & 103 & $102(49,76)$ & 5 & 1 & 8 & 3,76 & 14 \\
\hline \multicolumn{9}{|c|}{$\begin{array}{c}\text { По всем изученным хозяйствам области (без учёта типа подбора) } \\
\text { Чёрно-пёстрый скот }\end{array}$} \\
\hline 5168 & 4966 & 2800 & $2166(43,62)$ & 11 & 27 & 202 & 3,91 & 18 \\
\hline \multicolumn{9}{|c|}{ Симментальский } \\
\hline 1154 & 1108 & 550 & $558(50,36)$ & 8 & 6 & 46 & 3,99 & 38 \\
\hline \multicolumn{9}{|c|}{ Всё изученное поголовье } \\
\hline 6326 & 6074 & 3350 & $2724(44,85)$ & 19 & 32 & 248 & 3,92 & 56 \\
\hline
\end{tabular}

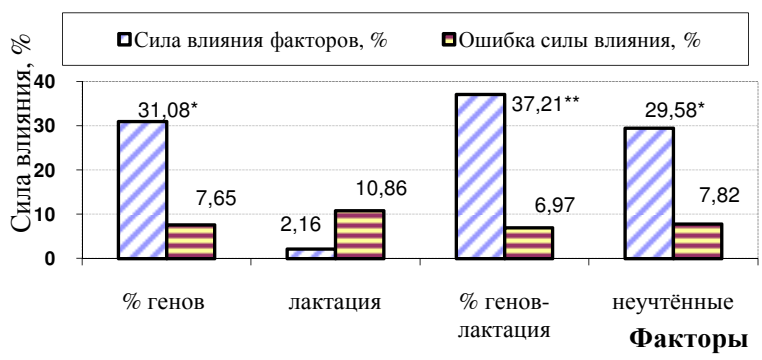

Рисунок 4 - Сила влияния факторов на множественные корреляции между удоем, жирностью молока и живой массой, $\%(*-\alpha<5 \%, * *-\alpha<1 \%)$

С увеличением доли генов голштинской породы до $50 \%(\mathrm{n}=1224)$ в стадах Орловской области возрастало количество мёртворожденных телят - от 1,97 до 5,96\% (см. рис. 5). В дальнейшем у адаптированных к условиям России коров с кровностью 87,5\% по голштинам наблюдалось уменьшение количества мёртворожденных телят $(1,96 \%)$, однако у завезённых из Германии, Венгрии и Ирландии чистопородных голштинов, не представленных на рисунке, проходили сложные процессы адаптации и наблюдались худшие воспроизводительные способности в сравнении с местным скотом.

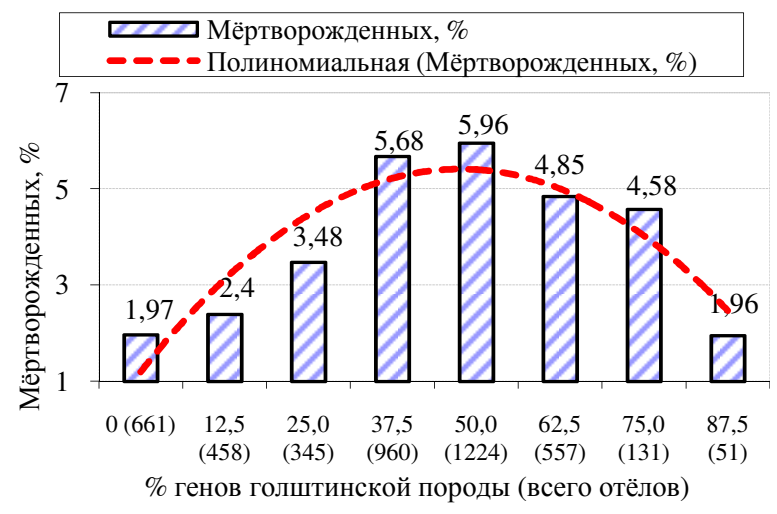

Рисунок 5 - Влияние голштинской породы на число мёртворожденных телят в хозяйствах Орловской области (\% ко всём отёлам) 


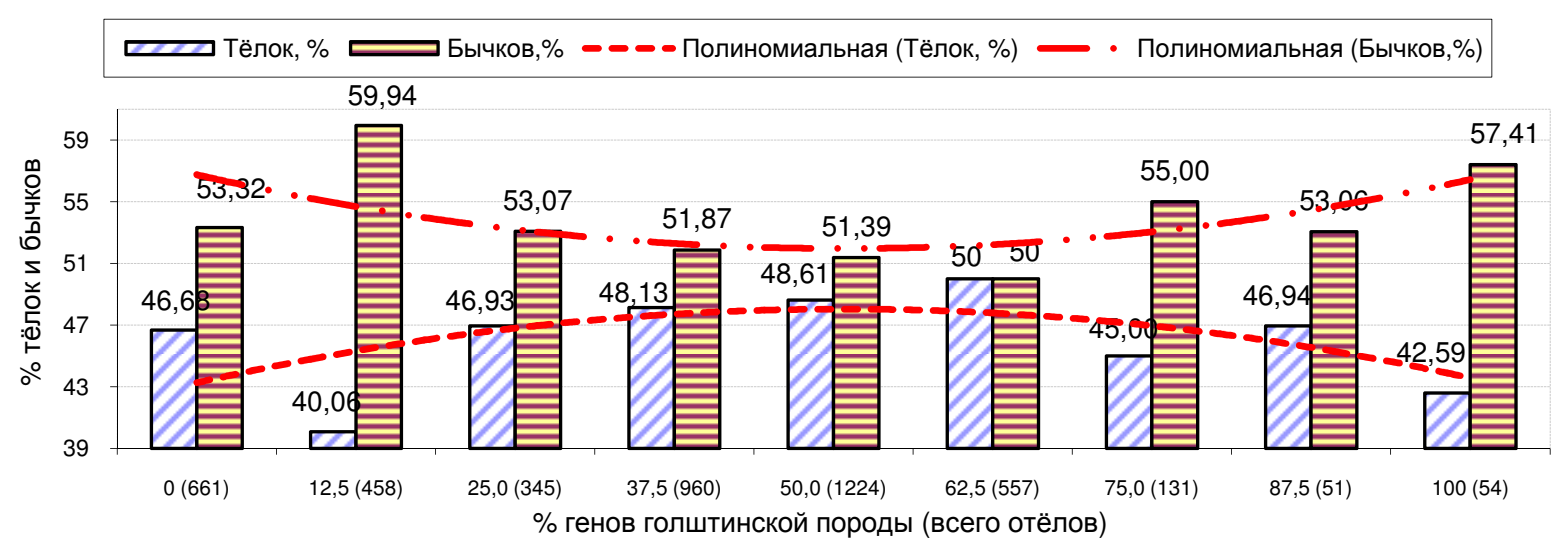

Рисунок 6 - Распределение полов в зависимости от процента генов голштинской породы в хозяйствах Орловской области

Наряду с рождением мёртвых телят, \% генов голштинской породы повлиял на процентное соотношение полов в потомстве (см. рис. 6). Так, при возрастании кровности от 12,5 до $62,5 \%$ по голштинам у коров в хозяйствах области процент рождения тёлок возрастал с 40,06 до 50,0\%, а затем прослеживалась тенденция к увеличению вероятности рождения бычков, то есть вероятность рождения тёлок следовала зависимости, которая может быть выражена уравнением параболы второго порядка. Возможно, данная тенденция связана с тем, что коровы с кровностью $12,5 \%$ генов по голштинам и чистопородные голштины имеют большую живую массу, а полукровные коровы являются средними по многим продуктивным показателям. Также следует заметить, что быки-производители давали разное соотношение полов в потомстве ОПХ «Стрелецкое» (см. рис. 7).

Так, у большинства быков ОАО «ЦСИО», семя которых использовалось в хозяйстве, вероятность рождения тёлки составляла от 20,59 до 34,43\%, у быков ОАО «Невское» (без кличек), которые находились на проверке в хозяйстве, процент рождения тёлок составил от 7,41 до $56,34 \%$.

Только у двух быков рождались преимущественно тёлки (Мороз 637 и №2205). Это позволяет сделать вывод о возможности увеличения поголовья тёлок в хозяйствах за счёт использования семени отдельных быков, являющихся улучшателями по молочной продуктивности дочерей. Также от быка Лидера 129 в 2008 году было рождено 10 мертвых телят, от Стажа 735 и Вальтера 739 - по 4, от Мейсона 5091 - 2, от ленинградских быков
№2205 и №1093 - 4 и 5 соответственно. Из 18 случившихся в хозяйстве абортов 5 приходилось на семя Мейсона 5091, по 3 на быков №4345 и Вальтера 739. При использовании семени Хана 1876, Люкса 21 и Мороза 637 не было ни абортов, ни мёртворожденных телят.

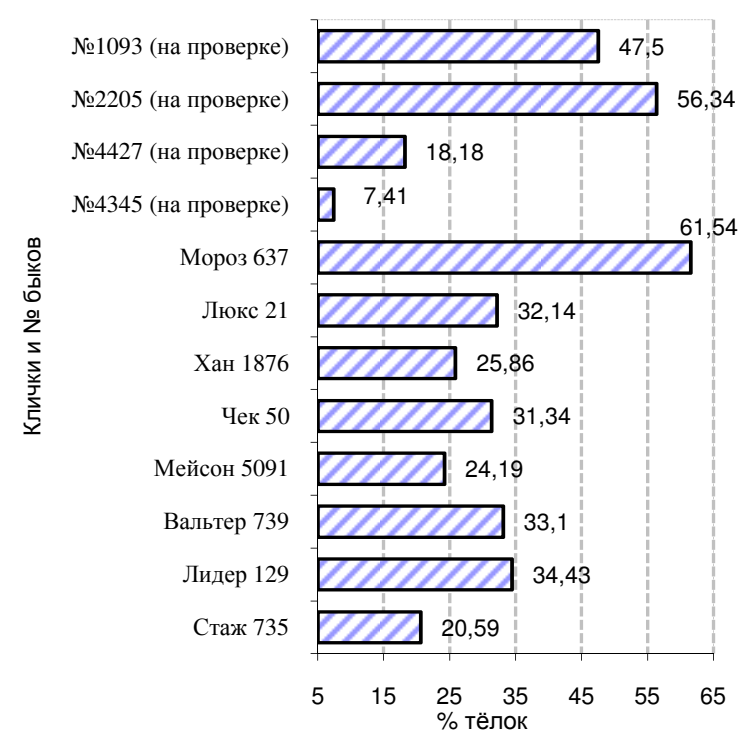

Рисунок 7 - Влияние быков-производителей на вероятность рождения тёлок в ОПХ «Стрелецкое»

Из таблицы 8 следует, что с 2001 по 2008 год у красно-пёстрых голштинских быков-производителей ОАО «ЦСИО» добавилось 16 эритроцитарных антигенов, 3 антигена выбыло, у чёрно-пёстрых голштинских быков добавилось 14 антигенов, выбыло 4. За тот же период времени при сравнении голштинов разной масти между собой было обнаружено 3 антигена, характерных для красно-пёстрых животных, и 22 антигена, харак- 
терных для чёрно-пёстрых животных. При этом чёрно-пёстрые голштины были значительно разнообразнее по иммуногенетиче- ским особенностям и имели наибольшее количество эритроцитарных антигенов в сравнении с изученными породами.

Таблица 8 - Динамика иммуногенетического полиморфизма у голштинских быков ОАО «ЦСИО»

\begin{tabular}{|c|c|c|c|c|}
\hline \multirow{3}{*}{ Порода } & \multicolumn{4}{|c|}{ Антигены } \\
\hline & \multirow{2}{*}{ Отсутствующие } & \multicolumn{2}{|c|}{ Изменения с 2001 года } & \multirow{2}{*}{ Характерные } \\
\hline & & Добавившиеся & Выбывшие & \\
\hline $\begin{array}{l}\text { Красно- } \\
\text { пёстрые } \\
\text { голштины }\end{array}$ & 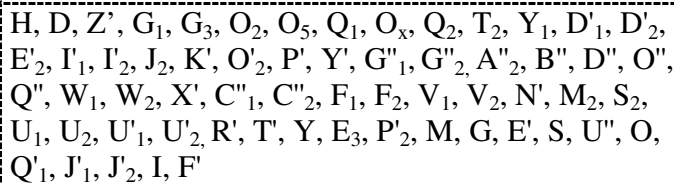 & $\begin{array}{l}\mathrm{A}_{2}, \mathrm{~B}_{1}, \mathrm{G}_{2}, \mathrm{I}_{1}, \mathrm{I}_{2}, \mathrm{O}_{3} \\
\mathrm{O}_{4}, \mathrm{P}_{2}, \mathrm{Q}, \mathrm{T}_{1}, \mathrm{C}_{2}, \mathrm{C}^{\prime \prime} \\
\mathrm{R}_{1}, \mathrm{~V}, \mathrm{~L}^{\prime}, \mathrm{G}^{\prime \prime}\end{array}$ & $\mathrm{O}_{2}, \mathrm{~J}_{1}, \mathrm{~K}^{\prime}$ & $\mathrm{O}_{3}, \mathrm{P}_{2}, \mathrm{~T}_{1}$ \\
\hline $\begin{array}{c}\text { Чёрно- } \\
\text { пёстрые } \\
\text { голштины }\end{array}$ & $\begin{array}{l}\mathrm{H}, \mathrm{D}, \mathrm{G}_{1}, \mathrm{O}_{3}, \mathrm{P}_{2}, \mathrm{~T}_{1}, \mathrm{O}_{5}, \mathrm{Q}_{1}, \mathrm{O}_{\mathrm{x}}, \mathrm{Q}_{2}, \mathrm{~T}_{2}, \mathrm{D}_{1}^{\prime}, \mathrm{D}_{2}^{\prime}, \mathrm{I}_{1}^{\prime}, \\
\mathrm{I}_{2}, \mathrm{~J}_{2}, \mathrm{O}_{2}^{\prime}, \mathrm{P}^{\prime}, \mathrm{Y}^{\prime}, \mathrm{G}_{2,} \mathrm{~A}_{2}, \mathrm{~B}^{\prime \prime}, \mathrm{D}^{\prime}, \mathrm{O}^{\prime \prime}, \mathrm{Q}^{\prime}, \mathrm{W}_{1}, \mathrm{~W}_{2}, \\
\mathrm{X}^{\prime}, \mathrm{C}^{\prime \prime}{ }_{1}, \mathrm{C}^{\prime \prime} \\
{ }_{2}, \mathrm{~F}_{1}, \mathrm{~F}_{2}, \mathrm{~V}_{1}, \mathrm{~V}_{2}, \mathrm{~N}^{\prime}, \mathrm{M}_{2}, \mathrm{~S}_{2}, \mathrm{U}_{1}, \mathrm{U}_{2}, \mathrm{U}_{1}^{\prime}, \\
\mathrm{U}_{2}^{\prime} \mathrm{R}^{\prime}, \mathrm{T}^{\prime}\end{array}$ & $\begin{array}{l}Z^{\prime}, \mathrm{G}_{3}, \mathrm{C}^{\prime}, \mathrm{Y}, \mathrm{E}_{3}, \mathrm{P}_{2}^{\prime}, \\
\mathrm{M}, \mathrm{G}, \mathrm{E}^{\prime}, \mathrm{O}, \mathrm{J}_{1}^{\prime}, \mathrm{J}_{2}^{\prime}, \mathrm{I}, \\
\mathrm{F}^{\prime}\end{array}$ & $\begin{array}{l}\mathrm{G}_{1}, \mathrm{~T}_{1}, \mathrm{Y}^{\prime}, \\
\mathrm{J}_{2}\end{array}$ & $\begin{array}{l}\mathrm{Z}^{\prime}, \mathrm{G}_{3}, \mathrm{O}_{2}, \mathrm{Y}_{1}, \mathrm{E}_{2}^{\prime}, \mathrm{K}^{\prime} \\
\mathrm{G}^{\prime \prime}{ }_{1}, \mathrm{U}_{1}, \mathrm{Y}, \mathrm{E}_{3}, \mathrm{P}_{2}^{\prime}, \mathrm{M} \\
\mathrm{G}, \mathrm{E}^{\prime}, \mathrm{S}, \mathrm{U}^{\prime \prime}, \mathrm{O}, \mathrm{Q}^{\prime}{ }_{1}, \mathrm{~J}^{\prime}{ }_{1} \\
\mathrm{~J}^{\prime}, \mathrm{I}, \mathrm{F}^{\prime}\end{array}$ \\
\hline
\end{tabular}

Общее иммуногенетическое сходство было максимальным между холмогорскими и чёрно-пёстрыми голштинскими быками «ЦИО» $(0,913)$ в связи со скрещиванием этих пород, между чёрно-пёстрыми голштинскими и чёрно-пёстрыми быками $(0,902)$, а также между голштинами разной масти в связи с родственным происхождением $(0,901)$ [42].

Нами также получены данные, в которых маркерная способность эритроцитарных антигенов возрастала с увеличением частоты встречаемости от 0,02 до 0,04. При этом наибольшим удоем обладали дочери чёрнопёстрых голштинских быков при частоте встречаемости антигенов больше 0,03 - 5194 кг молока, наблюдалось увеличение удоев у коров с частотой встречаемости антигенов ниже $0,01-4601$ кг молока по первой лактации. Это, по-видимому, объяснимо тем, что в популяции чёрно-пёстрого голштинизированного скота России в последние годы шло активное внедрение эритроцитарных антигенов, маркирующих высокий удой.

У чёрно-пёстрых голштинских быков, семя которых реализовывало ОАО «Орловское» в последние годы, 71 раз встречался антиген $\mathrm{F}, 30-\mathrm{H}^{\prime}, 25-\mathrm{X}_{2}, 24-\mathrm{W}, 23-\mathrm{Q}^{\prime}, 20-\mathrm{A}_{1}, 18$ - E, $17-\mathrm{Z}, 14-\mathrm{Y}_{2}, \mathrm{E}_{1}^{\prime}$ и $\mathrm{C}_{1}, 13-\mathrm{G}_{2}, 11-\mathrm{L}_{\text {и }} \mathrm{I}_{2}$, $10-\mathrm{O}_{1}, 9-\mathrm{S}_{1}$ и $\mathrm{C}_{2}$. При этом 34 антигена встречались от 2 до 5 раз, 24 - всего по одному разу. Это подтверждает активное внедрение в поголовье коров Орловской области разнообразных аллелей. Наиболее удачными при этом были быки с иммуногенетическим сочетанием $\mathrm{B}_{1} \mathrm{G}_{2} \mathrm{~K}$ - до 6578 кг молока и 246 кг молочного жира от 26 дочерей при оценке по качеству потомства.

Комплекс исследований, проведённых нами в отрасли свиноводства, позволяет обобщить несколько важных выявленных закономерностей:

1) в отечественном поголовье генетический потенциал многоплодия у свиноматок можно выразить уравнением нелинейной регрессии: $y_{x}=9,421+0,62058 x-0,0557 x^{2}$ (где $x-$ номер опороса), при этом наибольшее многоплодие характерно к 5-6 опоросу - до 11,1 поросёнка в среднем, после чего следует понижение до 10,05 голов к 10 опоросу;

2) у свиней с развитыми мясосальными качествами (см. рис. 8) прослеживалась наибольшая зависимость живой массы от обхвата груди $(\mathrm{r}=0,954)$ и длины туловища $(\mathrm{r}=0,829)$, в то время как между живой массой, обхватом груди и длиной туловища множественная корреляция $\left(\mathrm{r}_{\mathrm{x}(\mathrm{y}, \mathrm{z})}\right)$ составляла 0,955 , а живую массу $(x)$ можно было прогнозировать по обхвату груди (y) и длине туловища $(z)$ по формуле: $x_{y, z}=-30,0938-1,8143 y+3,4303 z$ (см. рис. 9);

3) на сегодняшний день, выразив 1991 год первым годом кризиса $(x)$, для прогноза поголовья свиней в России можно вывести две формулы, одна из которых является гиперболой первого порядка: $\bar{y}_{x}=15,833+\frac{23,3}{x}$ (при продолжении спада поголовья), вторая: $\bar{y}_{x}=19,24+\frac{19,007}{x^{2}}$, где $x-$ год от начала кризиса (при ослаблении спада поголовья). Это означает, что при сохранении тенденций отечественного свиноводства к 2040 году в России 
будет от 16,3 до 19,4 млн. голов свиней. Однако в случае увеличения поголовья в ближайшие 5-6 лет можно будет применять для построения уравнения прогноза параболу третьего порядка $\left(y_{x}=a+b x+c x^{2}+d x^{3}\right)$, а следовательно, при развитии отрасли к 2025 году можно будет получить до 23-25 млн. голов свиней.

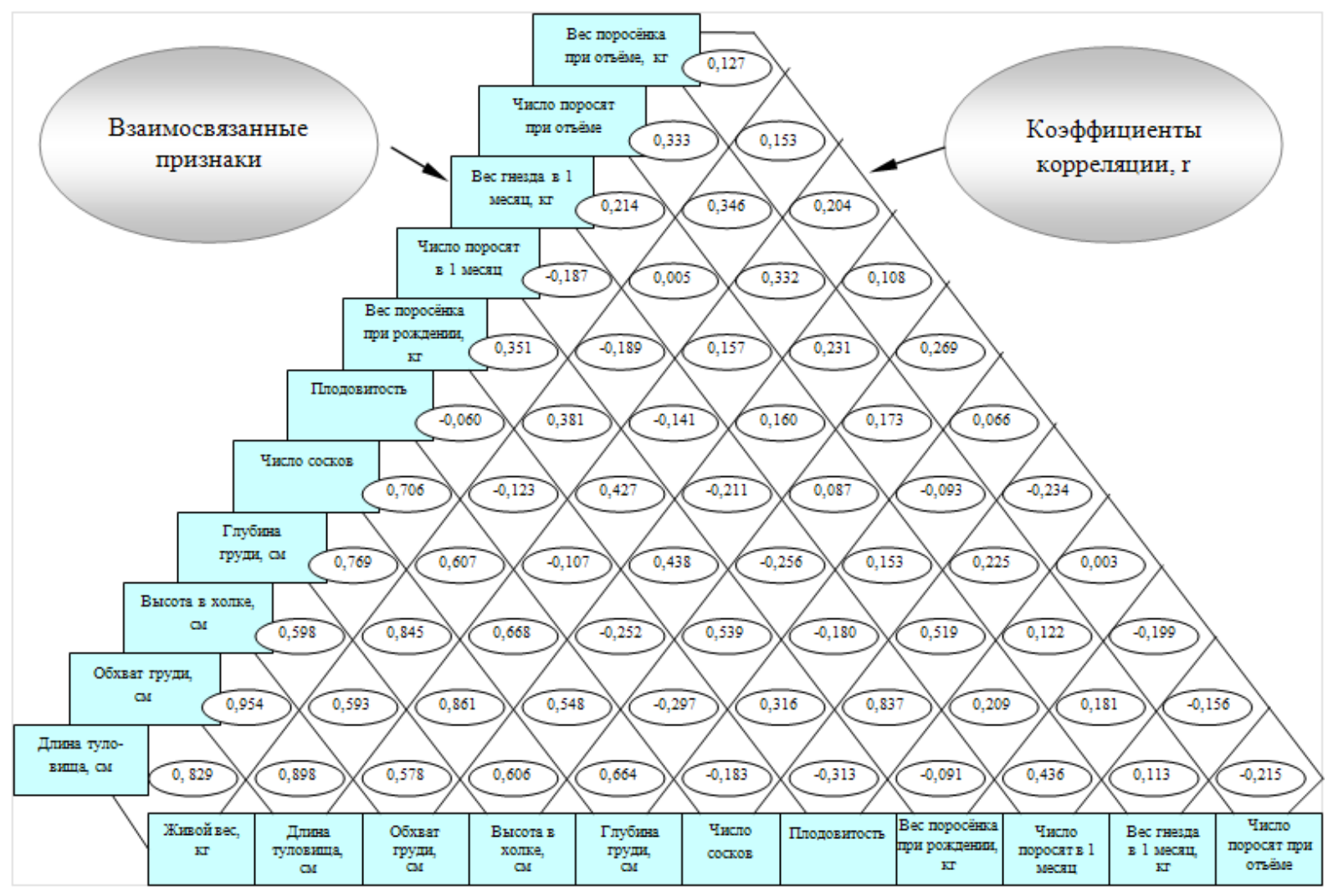

Рисунок 8 - Коэффициенты корреляции между селекционными признаками каликинской породы свиней, r

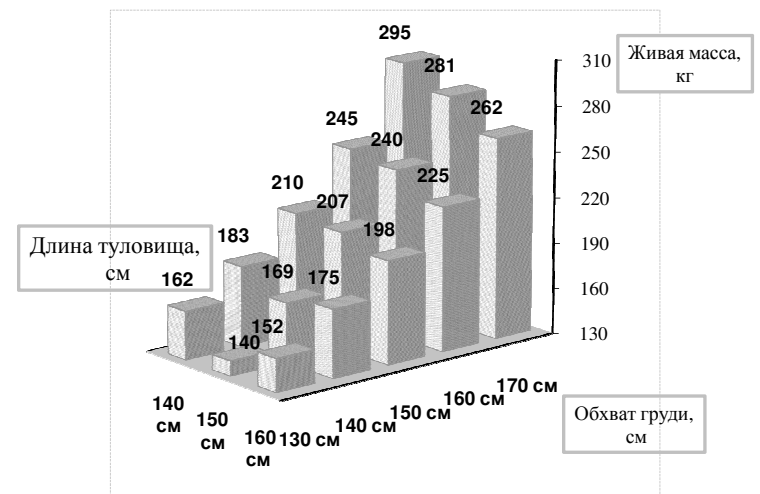

Рисунок 9 - Зависимость живой массы свиноматок от обхвата груди и длины туловища, кг

Ретроспективный анализ, проведённый нами, показал, что наименьшая общая фенотипическая изменчивость $(\mathrm{Cv})$ у свиноматок каликинской породы была характерна для количества сосков, высоты в холке, длины туловища и многоплодия - 3,1, 4,8, 4,1 и 4,9\% со- ответственно, а наибольшая - для живого веса свиноматок и количества поросят при отъёме $(14,0$ и $17,2 \%$ соответственно). При этом $\sigma$ по промерам колебалась от 3,4 см (глубина груди) до 9,9 см (обхват груди), по живому весу свиноматок составила 27,5 кг. В стаде ГПЗ им. Георгиевского за последние 10 лет отбора и селекционной работы живая масса ливенских хряков осталась приблизительно на прежнем уровне и в 2007 году составила 260,4 кг $(\mathrm{n}=42)$. При этом некоторое уменьшение их живой массы (на 2,1 кг) в сравнении с 2000 годом компенсировалось развитием мясных качеств и длины туловища (на 3,1 см). Проявлялась тенденция к возрастанию баллов за телосложение - с 90,7 до 91,2, несколько снизилась эффективность случек - с 84,0 до $81,4 \%$ (-2,6\%). Также наметилась тенденция увеличения многоплодия у дочерей - с 9,73 до 10,01 поросёнка, однако при этом уменьши- 
лось среднее количество поросят в 2 месяца (с 9,33 до 8,64 голов), что компенсировалось увеличением среднего веса 1 поросёнка в 2 месяца на 1,34 кг. Однако следует заметить, что отечественное поголовье свиней, разводимых в ЦФО, существенно уступает по мясным качествам импортным породам.

Также, применяя селекцию по генам в молочном скотоводстве, мы выяснили, что 18 швицких быков немецкого происхождения (47432 дочери) с генотипом ВВ по гену каппаказеина имели племенную ценность +699 кг молока и +24,5 кг молочного белка. По результатам оценки дочерей это превышало быков с генотипом АА на 103 кг молока и 2,5 кг молочного жира. Концентрация генотипа ВВ у швицких быков немецкого происхождения составила 0,474, а аллеля В по данному гену 0,685 .

Средний генетический потенциал чёрнопёстрых коров в Орловской области (PS) достигал 6500-8000 кг молока, симменталов 5000-5500 кг, голштинов - до 10000-11000 кг молока за 305 дней лактации. При этом в 2010 году в области насчитывалось более 1000 коров с удоями выше 7000 кг молока и 90 коров с удоями выше 10000 кг молока. В общей генетической изменчивости селекционных признаков на долю аддитивной изменчивости приходилось до 75-90\%, на случайные генетические эффекты - 10-25\%, при скрещивании неаддитивная изменчивость возрастала.

В целом наш опыт показывает, что большинство отечественных исследований по определению оптимальной кровности (\% генов) по голштинской породе проходило несистематизировано, носило периодический и поверхностный характер, в связи с этим возникло много интерпретаций и ложных выводов относительно эффективности скрещивания той или иной породы. Для устранения подобных ошибок в последующем целесообразно предложить новую схему постановки экспериментов по определению оптимального \% генов, сущность которой будет строиться по принципу нейронных технологий, применяемых в США (см. рис. 10).

Из рисунка 10 следует, что при определении оптимальной доли генов улучшающей породы при скрещивании новые генотипы следует испытывать в разных условиях корм- ления, при этом необходимо учитывать систему содержания, природно-климатические и, очевидно, экологические условия. Кроме того, при формировании групп по принципу параналогов каждая из них должна включать в себя животных нескольких линий, полученных от 3-5 отцов-производителей. Для уменьшения затрат при эксперименте следует создавать разные рационы только для 2 -3 генотипов, в дальнейшем, исходя из результатов, корректировать исследования. Однако приведённое количество кормовых единиц в схеме условно и может быть изменено, в зависимости от вида и породы животных.

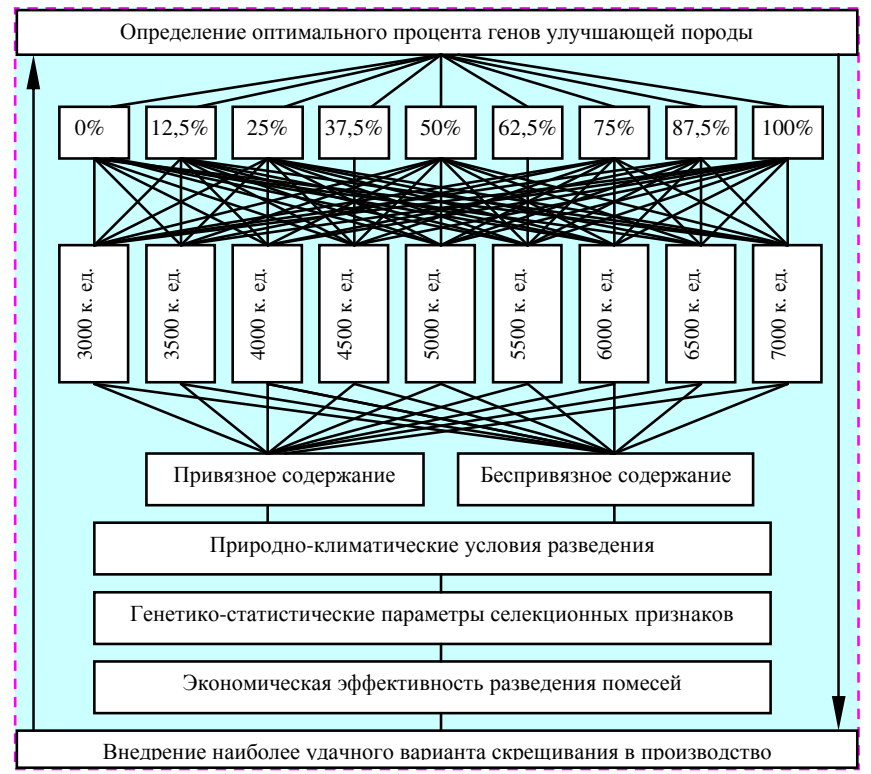

Рисунок 10 - Схема определения птимального процента генов у помесей

В современной селекции также необходимо использовать комплексный подход при оценке племенной ценности быковпроизводителей по молочной продуктивности дочерей (см. рис. 11).

Для устранения погрешностей при оценке следует закреплять семя быков по разным хозяйствам (их количество может составлять от 15 до 30 и более. При таком подходе будет нивелироваться влияние факторов кормления и содержания на результаты оценки, поскольку, как следует из результатов наших исследований, действие фактора «стадо» на продуктивные и экономические показатели огромно. 


\section{A. SHENDAKOV, Orel State Agrarian University}

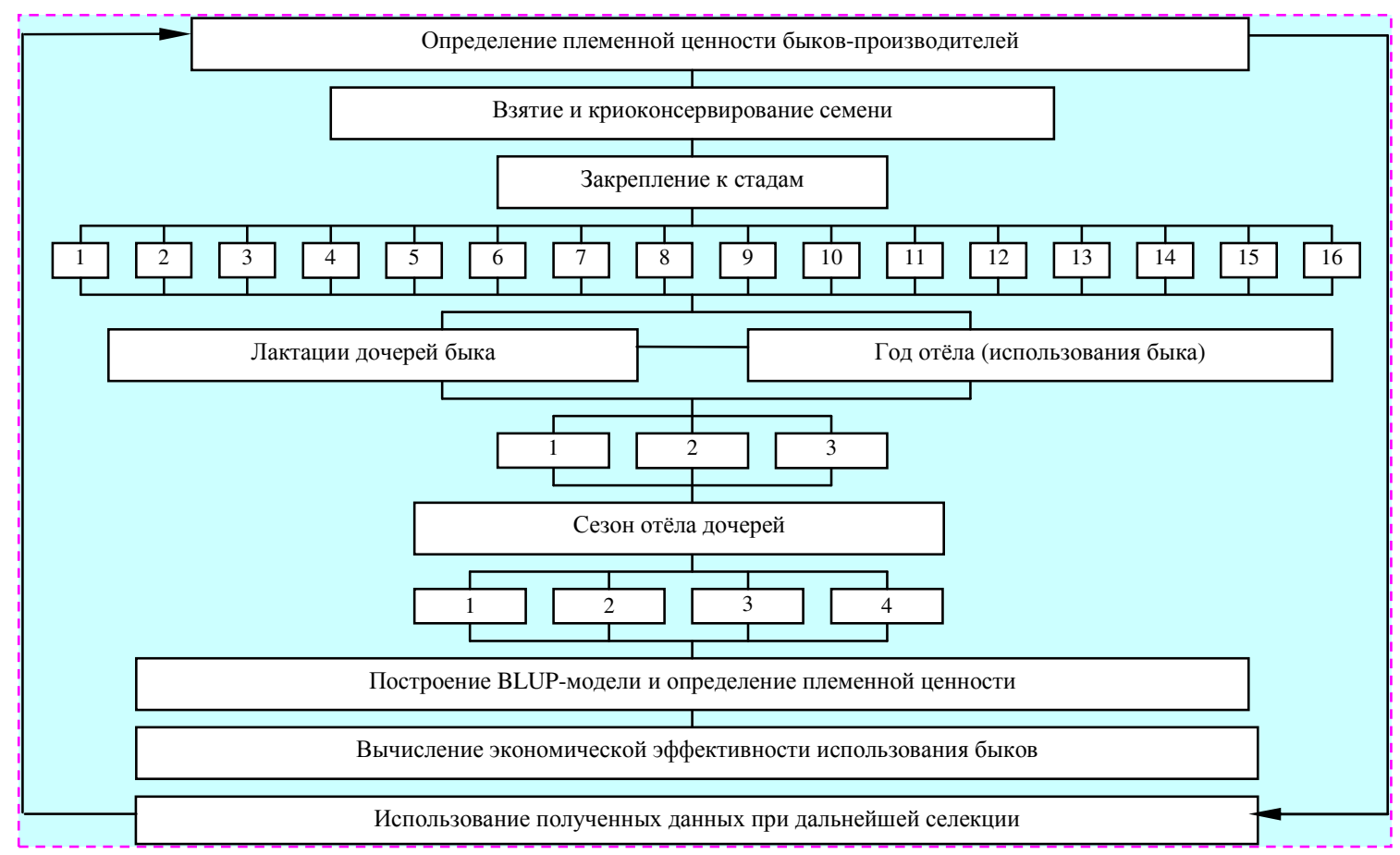

Рисунок 11 - Схема BLUP-оценки быков по молочной продуктивности дочерей

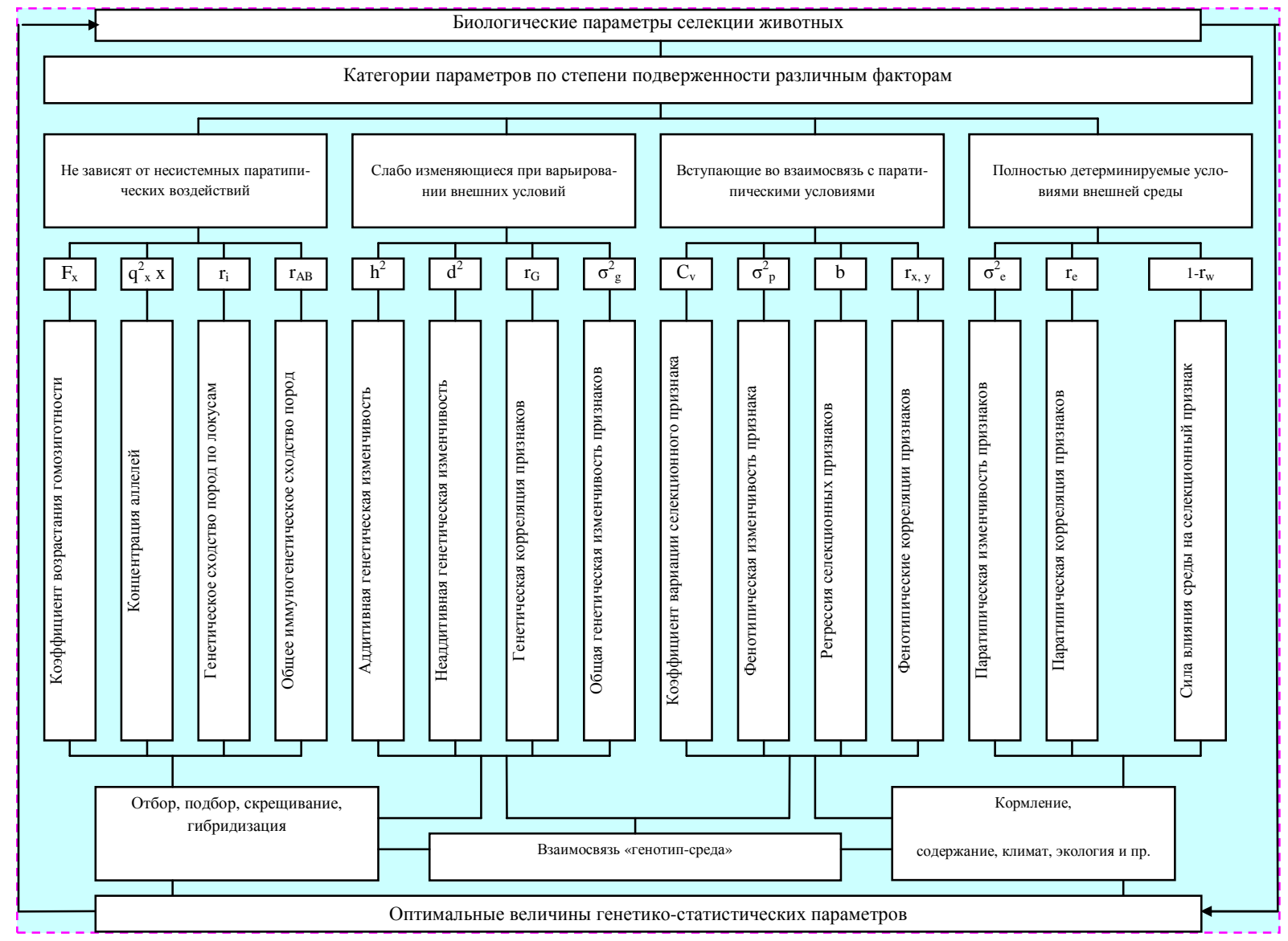

Рисунок 12 - Схема управления биологическими параметрами селекции в популяциях животных 
С целью более чёткого представления о племенной ценности быка необходимо учитывать молочную продуктивность его дочерей по 3 лактациям в течение нескольких лет (от 3 и более), ежегодно при получении новых данных следует корректировать результаты оценки. При этом также следует учитывать и влияние других факторов на результаты оценки, таких, как сезон и пр.

Наши исследования позволяют сделать общение биологических параметров и сформировать их по степени подверженности генетическим и пространственным факторам в четыре категории (см. рис. 12), согласно которым можно выделить параметры, полностью зависящие от генетических факторов, слабо изменяющиеся при варьировании внешних условий, активно вступающие в взаимодействие со средой и зависящие только от внешних условий. На каждый из перечисленных в схеме параметров существуют силы воздействия, а следовательно, на эффективность селекции.
Таким образом, использование в селекции сельскохозяйственных животных подробных методов генетико-статистического анализа позволяет выявить многие скрытые процессы, протекающие в стадах, а также важные для теории науки и практики животноводства биологические закономерности. В России и Орловской области существуют предпосылки увеличения молочной продуктивности коров в связи с наличием достаточно высокой генетической изменчивости селекционных признаков. Наличие положительной генетической корреляции между селекционными признаками может позволить быстрое увеличение целого ряда продуктивных показателей в стадах молочных коров. В области намечены резервы увеличения поголовья тёлок и мясной продуктивности свиней. Проведённые исследования в перспективе позволят ускорить работу по выведению нового типа скота и начать модернизацию селекции местных свиней Орловской области, включая применение BLUP.

\section{БИБЛИОГРАФИЯ}

Бакай, А.В. Генетика [Текст]/ А.В. Бакай, И.И. Кочиш, Г.Г. Скрипниченко. М.:КолосС, 2007.-448 с.

Букаров, Н. Новый уровень познания маркерных генов групп крови у скота [Текст] / Н. Букаров, Е. Лебедев, И. Морозов // Молочное и мясное скотоводство.- 2005. - №7. - С. 39-41.

Буяров, В.С. Эффективность селекции молочного скота [Текст] / В.С. Буяров, А. И. Шендаков, Т.А. Шендакова // Животноводство России. - 2011. - №1. - С. 41-44.

Генджиева, О. Б. Изучение генетического разнообразия калмыцкого скота с использованием ISSR-фингерпринга [Текст] / О. Б. Генджиева, Г. Е. Сулимова // Зоотехния. - 2009. - №3. - С. 4-5.

Исламова, С. Порода и антигенный состав крови быков-производителей [Текст] / С. Исламова, Ф. Исламов // Молочное и мясное скотоводство. - 2006. - №5. - С. 34-35.

Исламова, С. Применение ДНК-технологии в селекции [Текст] / С. Исламова, Ф. Исламов, И. Долматова и др. // Молоч- ное и мясное скотоводство.- 2005. №5. - C. 2-4.

Коровушкин, А.А. Иммуногенетические маркеры устойчивости коров к заболеваниям [Текст] / А. А. Коровушкин // Зоотехния. - 2004. - №6. - С. 9-11.

Крюков, В.И. Совершенствование симменталов в СПК «Фатневский» [Текст] / В. И. Крюков, А. И. Шендаков, В. М. Николина // Зоотехния. - 2004. - №6.- С. 11.

Кузнецова, И. В. Мониторинг генетической структуры популяции крупного рогатого скота чёрно-пёстрой породы [Текст] / И. В. Кузнецова // Зоотехния. - 2009. №2. - C. 2-3.

Кузнецов, В. М. Основы научных исследований в животноводстве [Текст] /В. М. Кузнецов. - Киров, Изд. Зонального НИИСХСВ. - 2006. - 568 стр.

Кузнецов, В. М. Разработка оптимальных программ селекции в молочном скотоводстве / В. М. Кузнецов // Зоотехния. 1996. - №1. - C. 5-13.

Кузнецов, В. М. Современные методы анализа и планирования селекции в молоч- 
ном стаде [Текст]. - Киров, Изд. Зонального НИИСХСВ. - 2001. - 116 стр.

Лакин, Г. Ф. Биометрия [Текст] / Г. Ф. Лакин. - М.: Высшая школа. - 1990. - 352 с.: ил.

Ляшук, Р. Н. Совершенствование чёрнопёстрого скота в Орловской области [Текст] / Р. Н. Ляшук, А. И. Шендаков, М. В. Востров // Молочное и мясное скотоводство. - 2005. - №7. - С. 20-22.

Ляшук, Р. Н. Совершенствование молочного скота в Орловской области [Текст] / Р.Н. Ляшук, А.И. Шендаков, М.В. Востров //Молочное и мясное скотоводстBo.- 2007. - №1. - C. 22-26.

Ляшук, Р. Н. К вопросу о голштинизации чёрно-пёстрого скота в Орловской области [Текст] / Р.Н. Ляшук, А.И. Шендаков, М.В. Востров, В. В. Сорокин //Вестник ОрёлГАУ. - 2007. - №1. - С. 38-41.

Ляшук, Р.Н. Результаты селекции молочного скота в Орловской области [Текст] / Р.Н. Ляшук, А.И. Шендаков //Аграрная наука. - №9. - 2007. - С. 25-27.

Ляшук, Р. Н. Повышение генетического потенциала молочного скота [Текст] / Р.Н. Ляшук, А. И. Шендаков, М. В. Востров, В. В. Сорокин // Зоотехния. - 2007. №11. - C. 3-6.

Ляшук, Р. Н. Зоотехнические аспекты реализации продуктивного потенциала голштинизированного чёрно-пёстрого скота [Текст] / Р.Н. Ляшук, А.И. Шендаков, В.В. Сорокин, Е.Г. Амелин // Аграрная наука. - №2. - 2008. - С. 20-22.

Ляшук, Р. Н. Селекционно-генетическая оценка быков-производителей по потенциалу молочной продуктивности [Текст] / Р.Н. Ляшук, А.И. Шендаков, Т. А. Шендакова // Сельскохозяйственная биология. - 2008. - №4. - С. 23-29.

Ляшук, Р. Н. Совершенствование системы отбора молочного скота [Текст] / Р.Н. Ляшук, А.И. Шендаков, Т.А. Шендакова, В.В. Машкей // Аграрная наука. 2008. - №8. - С. 31-34.

Ляшук, Р. Н. Повышение генетического потенциала молочного скота [Текст] / Р.Н. Ляшук, А.И. Шендаков, В.В. Сорокин // Зоотехния. - 2009. - №3. - С. 2-3.

Ляшук, Р. Н. Основные направления развития молочного скотоводства в Орлов- ской области [Текст] /Р. Н. Ляшук, В. Н. Масалов, А. И. Шендаков // Вестник ОрёлГАУ. - 2011. - №1. - С. 9-13.

Ляшук, Р. Селекционно-генетический потенциал импортированного молочного скота [Текст] / Р. Н. Ляшук, А. И. Шендаков, А. В. Сурженков // Вестник ОрёлГАУ. - 2010. - №2. - С. 30-32.

Меркурьева, Е. К. Генетика [Текст] /Е. К. Меркурьева, 3. В. Абрамова, А. В. Бакай и др. - М.: Агропромиздат. - 1991. - 446 с.: ил.

Романенко, Г. А. Генетические маркеры в селекции уральского чёрно-пёстрого скота [Текст] /Г. А. Романенко // Аграрный вестник Урала. - 2009. - №4. - С. $82-83$

Самусенко, Л.Д. Разведение симментальского скота по линиям в Орловской области [Текст] / Л. Д. Самусенко, А. И. Шендаков // Зоотехния. - 2009. - №6. C. $2-4$.

Терлецкий, В. П. Оценка племенных животных по полиморфизму генов и ДНК / В. П. Терлецкий, Н. В. Дементьева, Е. С. Усенбеков // Зоотехния. - 2001.-№1.- С. 14-16.

Тинаев, А. Племенные ресурсы быковпроизводителей чёрно-пёстрой породы / А. Тинаев, Л. Калашникова, Т. Ганченкова [Текст] // Молочное и мясное скотоводство.- 2009. - №1. - С. 5-7.

Тинаев, А. Хозяйственно-полезные признаки чёрно-пёстрого скота с разными генотипами каппа-казеина [Текст] / А. Тинаев, Л. Калашникова, К. Аджибеков // Молочное и мясное скотоводство.2005. - №5. - C. 30-32.

Хайруллина, Н. Влияние сочетания локусов эритроцитарных антигенов быковпроизводителей на структуру стада крупного рогатого скота / Н. Хайруллина, Н. Фенченко, 3. Ярмухаметова, Р. Ахмадуллин // Зоотехния. - 2007. - №6. - C. 5-6.

Черных, А. Генотип каппа-казеина и качество молока чёрно-пёстрых коров / А. Черных, Л. Калашникова [Текст] // Молочное и мясное скотоводство.- 2008. №5. - С. 9-10.

Шендаков, А.И. Молочная продуктивность симментал-голштинских коров [Текст] / А. И. Шендаков // Молочное и мясное 
скотоводство. - 2002. - №2.- С 16-17.

Шендаков, А.И. Влияние генотипа коров на сыропригодность молока [Текст] / А. И. Шендаков, В. Н. Данилов, В. И. Крюков // Молочное и мясное скотоводство. 2003.- №8. - С. 16-18.

Шендаков, А.И. Сыропригодность молока симментальских коров и помесей [Текст] / А. И. Шендаков, В. И. Крюков, В. Н. Данилов // Зоотехния. - 2004. №2.- С. 29-30.

Шендаков, А. И. Совершенствование симментальского скота в Орловской области [Текст] / А. И. Шендаков, В. И. Крюков // Молочное и мясное скотоводство. - 2004. - №7. - C. 10-11.

Шендаков, А. И. Использование потенциала голштинского скота [Текст] / А. И. Шендаков // Зоотехния. - 2005. - №8.C. 5-7.

Шендаков, А.И. Устойчивость признаков у симментал-голштинских коров [Текст] / А. И. Шендаков // Зоотехния. - №7. 2006. - C. 4-5.

Шендаков, А. И. Совершенствование симментальского скота в Орловской области [Текст] / А. И. Шендаков, В. И. Крюков // Зоотехния. - №7. - 2007. - С. 4-6.

Шендаков, А. И. Состав, качество и сыропригодность молока коров в зависимости от генотипа [Текст] / А. И. Шендаков, В. И. Крюков // Известия Орловского ГТУ, серия «Легкая и пищевая промышленность». - 2003. - № 3-4.

Шендаков, А. И. Модернизация селекции в молочном скотоводстве Орловской области [Текст] / А. И. Шендаков // Молочное и мясное скотоводство.- 2008. №6. - С. 15-19.

Шендаков, А. И. Генетические аспекты модернизации молочного скотоводства [Текст] / А. И. Шендаков, Т. А. Шендакова //Вестник Орёл ГАУ. - 2009. - №2. - C. 30-35.

Шендаков, А. И. Результаты использования потенциала голштинского скота в Орловской области [Текст] / А. И. Шендаков // Зоотехния. - 2010. - №2. - С. 6-9. 23.
Шендаков, А. И. Комплексный анализ результатов селекции молочного скота в Орловской области / А. И. Шендаков //Вестник ОрёлГАУ. - 2010. - №2. - С. $16-22$.

Шендаков, А. И. Результаты голштинизации молочного скота в Орловской области [Текст] / А. И. Шендаков // Аграрный вестник Урала. - 2010. - №11(77). - С. 70-72.

Шендаков, А. И. Влияние генетических и средовых факторов на интенсивность роста и молочную продуктивность чёрно-пёстрого голштинизированного скота [Текст] / А.И. Шендаков, Т. А. Шендакова // Вестник ОрёлГАУ. - 2010. №5. - С. 83-90.

Шендаков, А. И. Оценка эффективности отбора скота чёрно-пёстрой породы по молочной продуктивности [Текст] / А.И. Шендаков // Вестник ОрёлГАУ. 2010. - №6. - С. 93-100.

Шендаков, А. И. Результаты использования генетического потенциала молочного и комбинированного скота в Орловской области [Текст] / А.И. Шендаков, Т. А. Шендакова // Вестник ОрёлГАУ. - 2011. - №1. - C. 14-21.

Шилер, Р. Селекция в животноводческой практике [Текст]. /Р. Шилер, Я. Вахал, Я. Винш, перевод с чешского Г. Н. Мирошниченко, под редакцией Д. В. Карликова. - М. Колос. - 1981.

Эрнст, Л. К. Изучение влияния прилития крови голштинского скота на изменение генофонда крупного рогатого скота отечественных пород с использованием ДНК-микросателлитов [Текст] / Л. К. Эрнст, Н. А. Зиновьева, Е. Н. Коновалова и др. // Зоотехния. - 2007. - №12. - С. 2-5.

Houle, D. Comparing Evolvability and Variability of Quantitative Traits [Text] /D. Houle //Genetics. - 1992. - 130:195-204.

Parland, S. Mc. Inbreeding effect on milk production, calving performance, fertility, and conformation in Irish Holstein-Friesians [Text] / S. Mc. Parland, J. F. Kearney, M. Rath, D. P. Berry // Dairy Science. - 2007. - 90:4411-4419. 